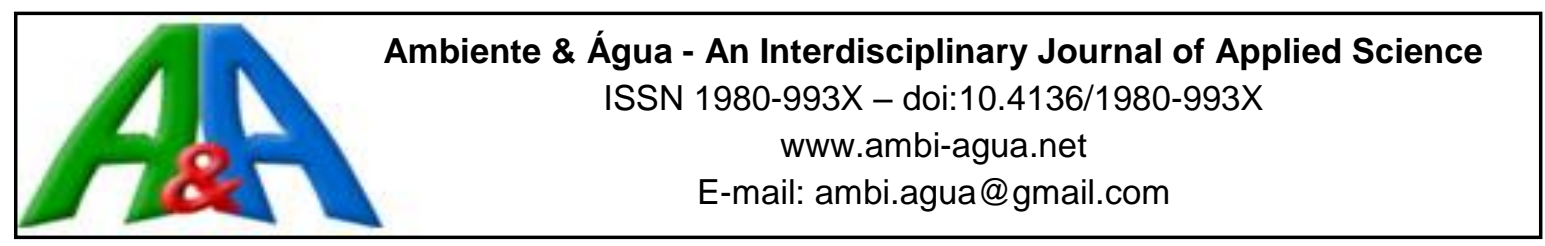

\title{
Soil map units of Minas Gerais State from the perspective of Hydrologic Groups
}

\author{
ARTICLES doi:10.4136/ambi-agua.2118
}

Received: 27 Mar. 2017; Accepted: 20 Nov. 2017

\section{Lucas Alves da Silva ${ }^{1}$; Antônio Marciano da Silva ${ }^{2}$; Gilberto Coelho'; Leandro Campos Pinto ${ }^{3^{*}}$}

\author{
${ }^{1}$ Universidade Federal de Lavras (UFLA), Lavras, MG, Brasil \\ Departamento de Engenharia. E-mail: lucasas@deg.ufla.br, coelho@deg.ufla.br \\ ${ }^{2}$ Universidade Federal de Alfenas (UNIFAL), Poços de Caldas, MG, Brasil \\ Departamento de Engenharia. E-mail: antonio.marciano@unifal-mg.edu.br \\ ${ }^{3}$ Universidade Federal de Lavras (UFLA), Lavras, MG, Brasil \\ Departamento de Ciência do Solo. E-mail: leandcampos@yahoo.com.br \\ *Corresponding author
}

\begin{abstract}
The knowledge of water availability is the basis for water resource planning and management. The Soil Map Units of the State of Minas Gerais were interpreted from the perspective of Hydrologic Groups based on the Curve Number - Soil Conservation Service method, with the addition of pedological elements of the mapped units. The generated products were used in three different physiographic environments of the Minas Gerais State. According to results, most of Minas Gerais falls within Hydrologic Groups A and B, indicating that the soils in these areas present low surface runoff and high water infiltration rates. The characterization and spatialization of the hydrological regime, with emphasis on information about the soils of Minas Gerais, as applied this study, has a level of detail not yet employed in studies of this scope, apart from the initiative to interpret them from the perspective of soil hydrological groups. The mapping of the three water resources planning and management units, composed of distinct environments, from the perspective of hydrological groups, allowed verification of the proposed methodology's potential, which can be used to support the management and planning of the water resources of Minas Gerais. Interpretive studies of soil maps from a hydrological perspective are essential to improve our understanding of water surpluses in a given region.
\end{abstract}

Keywords: curve number method, planning and management units, water resources.

\section{Unidades de mapeamento de solos de Minas Gerais sob a perspectiva de Grupos Hidrológicos}

\section{RESUMO}

O conhecimento da disponibilidade hídrica é básico para a gestão e planejamento dos recursos hídricos. O objetivo deste trabalho foi interpretar as unidades de mapeamento de solos do estado de Minas Gerais sob a ótica dos grupos hidrológicos conforme método do Número da Curva (Curve Number - Soil Conservation Service). Para avaliar os produtos gerados, aplicou-se o procedimento em três ambientes fisiográficos distintos do estado. De acordo com os resultados, a maior parte do estado de Minas Gerais se enquadra nos Grupos Hidrológicos A 
e B, indicando que os solos nestas áreas apresentam baixo escoamento superficial e alta taxa de infiltração de água. A caracterização e espacialização do regime hidrológico, com ênfase na informação sobre os solos do Estado de Minas Gerais, aplicados neste estudo, tem um nível de detalhe ainda não empregado em estudos deste escopo, além da iniciativa de interpretá-los na perspectiva de grupos hidrológicos do solo. O mapeamento das três unidades de planejamento e gestão de recursos hídricos, compostas por ambientes distintos, na perspectiva dos grupos hidrológicos, permitiu verificar a potencialidade da metodologia proposta, que pode ser utilizada para subsidiar a gestão e o planejamento dos recursos hídricos do Estado de Minas Gerais. Estudos sobre interpretações de mapas de solo do ponto de vista hidrológico são essenciais para melhorar a nossa compreensão sobre os excedentes de água em determinada região.

Palavras-chave: método do número da curva, unidades de planejamento e gestão, recursos hídricos.

\section{INTRODUCTION}

The Curve Number method $(\mathrm{CN})$ is an empirical model for predicting direct runoff. It was developed by the United States Department of Agriculture (USDA) Soil Conservation Service (SCS) (Arnold et al., 1995), and groups soils into four hydrological groups (HG's) (A, B, C, and D). These groups correspond to decreasing degrees of infiltration capacity and, therefore, increasing direct surface runoff.

Grimaldi et al. (2013) revealed limitations of the SCS-CN method and proposed a methodology that combines the simplicity of the SCS-CN method and the physical behavior of the Green-Ampt model, obtaining satisfactory results.

Ogden et al. (2017) demonstrated the well-documented limitations of the SCS-CN method and the need for advances in this kind of method. However, even with the SCS-CN method model limitations, it is still used successfully today, whether in engineering designs, or inserted in parts of other models (Mello et al., 2016).

In Brazil, one of the difficulties to estimate $\mathrm{CN}$ is related to the soil hydrological classification, because there are soils that do not fit in hydrologic groups defined by the SCS (Sartori et al., 2005). Thus, their adaptation for use in tropical regions requires an adequate calibration to obtain consistent results (Mello and Silva, 2013).

An important step in calibration is the classification of soil into hydrologic groups; however, there is a great divergence between the methods used in this classification that generally are based on soil hydraulic conductivity values, infiltration capacity or soil particle size distribution (Fiori et al., 2010). Sartori et al. (2005) proposed a classification of the hydrologic groups for the soils of São Paulo State, where the authors highlighted the differentiated behavior between the soils of this state without hydrologic classification and soils to which a hydrologic classification had been assigned. Thus, an alternative or complementary methodology, such as the one presented in this work, is important to assist in the differentiation of the hydrologic groups of Minas Gerais State.

The methodology presented does not restrict the classification to only one soil property, as commonly done in hydrologic classification, but encompasses the current body of knowledge regarding soil water behavior, which allows a better adjustment of hydrological models.

A major hypothesis of the study is that the availability of surface runoff estimation and the interpretation of soil mapping units, from the perspective of the Hydrologic Groups of Minas Gerais State, will support the management and planning of water resources.

The aim of this study was the interpretation of soil mapping units of the Minas Gerais State (FEAM 2010) from the perspective of the Hydrologic Groups, according to the Curve Number method developed by the SCS-USDA, USA. 


\section{MATERIAL AND METHODS}

Using the SCS-CN method (SCS-USDA), we developed an interpretation of the soil mapping units of the Minas Gerais State (Figure 1 and Table 1) from the perspective of the HG's, where, for this activity, we collaborated with a group of specialists in soil hydrology.

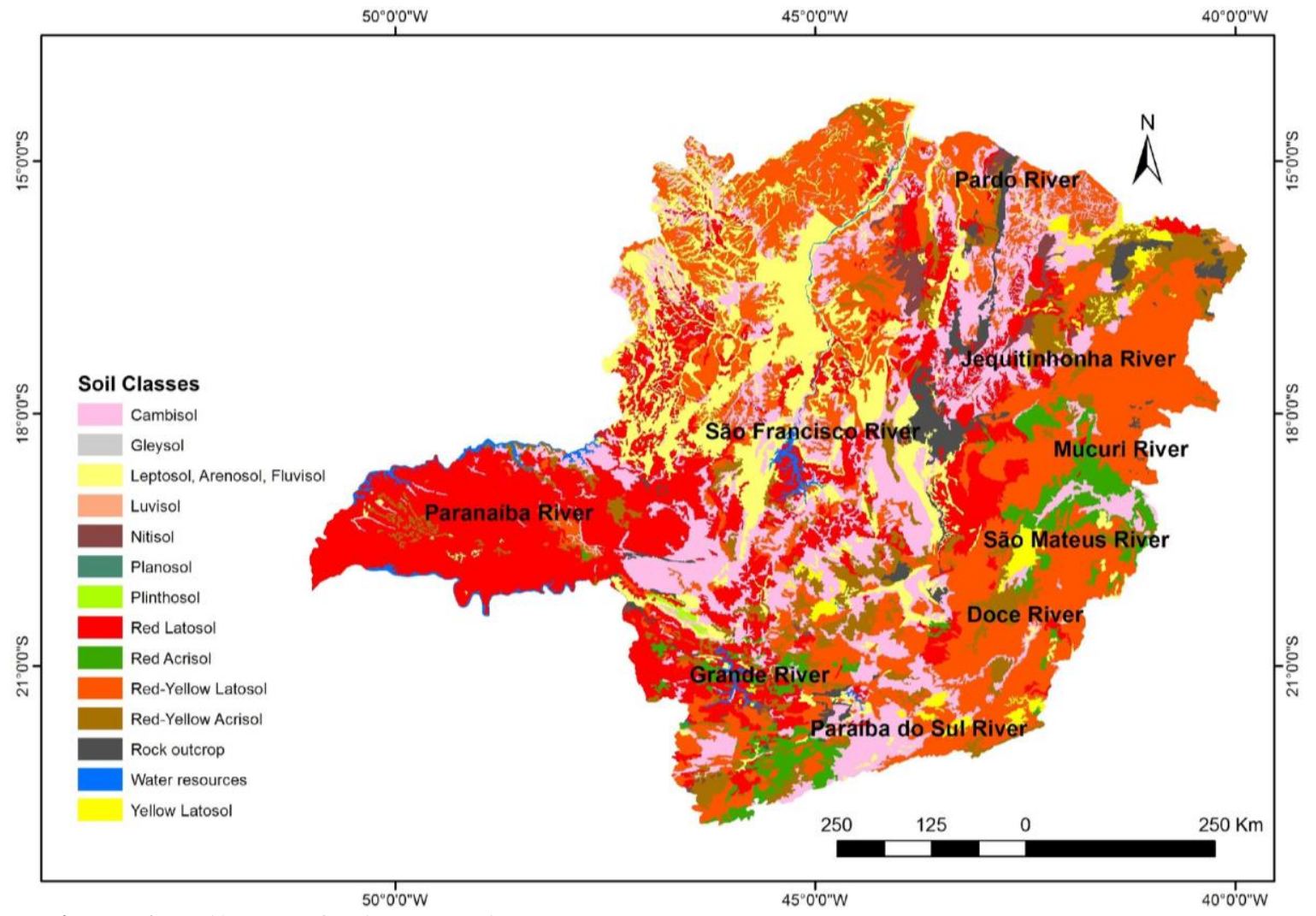

Figure 1. Soil map of Minas Gerais State.

Source: Adapted from FEAM (2010).

Table 1. Geographical expression of the soil classes for Minas Gerais

State.

\begin{tabular}{lcc}
\hline Soils & Area (ha) & Area (\%) \\
\hline Red-Yellow Latosol & $17,483,021$ & 30.05 \\
Red Latosol & $13,253,798$ & 22.78 \\
Cambisol & $10,170,003$ & 17.48 \\
Leptosol, Arenosol, Fluvisol & $7,349,167$ & 12.63 \\
Red-Yellow Ultisol & $4,545,443$ & 7.81 \\
Red Ultisol & $2,064,499$ & 3.55 \\
Rock outcrop & $1,442,772$ & 2.48 \\
Yellow Latosol & 953,642 & 1.64 \\
Nitisol & 574,400 & 0.99 \\
Gleysol & 232,459 & 0.40 \\
Plinthosol & 64,611 & 0.11 \\
Luvisol & 37,458 & 0.06 \\
Planosol & 5,063 & 0.01 \\
\hline Total & $58,176,336$ & 100 \\
\hline
\end{tabular}


According to Table 1, Red-Yellow Latosol is the most frequent soil class in Minas Gerais State $(30.05 \%)$ followed by Red Latosol $(22,78 \%)$ and Cambisol $(17,48 \%)$. These three soil classes count for approximately $70 \%$ of the Minas Gerais State area.

Using the soil class data (Figure 1 and Table 1), it was possible to incorporate pedological elements and the water behavior of the mapped pedological units into the interpretation.

This approach is advantageous because it does not define the hydrological group classification based only one soil property as an indicator of soil infiltration capacity, a situation that may be applicable to temperate regions, but must be adapted to the conditions of tropical soils.

Based on the criteria adapted from Mello and Silva (2013) (Table 2), we associated the soil classes of the mapping units to the HG's, with the incorporation of infiltration capacity values proposed by McCuen (1998).

Table 2. Hydrological Groups and soil characteristics.

\begin{tabular}{|c|c|}
\hline Hydrological Groups & Soil characteristic \\
\hline A & $\begin{array}{l}\text { High soil water infiltration, with soil basic infiltration velocity (BIV) higher } \\
\text { than } 7.62 \mathrm{~mm} \mathrm{~h}^{-1} \text {. According to tropical and subtropical soil genesis, very } \\
\text { deep soils }(>2.0 \mathrm{~m} \text { ) with high permeability and low soil erodibility fit in this } \\
\text { hydrological group (due to their texture and granular structure). Have a } \\
\text { horizon A/horizon B texture ratio lower than } 1.2 \text { (without a natural } \\
\text { impediment layer). Red and Red-Yellow Latosols can be included in this } \\
\text { group. Not susceptible to erosion. }\end{array}$ \\
\hline B & $\begin{array}{l}\text { Less permeable than soils of Group A, therefore generate more runoff, with } \\
\text { BIV values between } 3.81 \text { e } 7.62 \mathrm{~mm} \mathrm{~h}^{-1} \text {. Deep soils }(1.0 \text { a } 2.0 \mathrm{~m}) \text {, with } \\
\text { adequate permeability. Have a horizon A/horizon B ratio between } 1.2 \text { and } \\
1.5 \text {, such as Acrisols and some Latosols with sandy horizon A and denser } \\
\text { horizon B. More susceptible to erosion than Group A. }\end{array}$ \\
\hline $\mathrm{C}$ & $\begin{array}{l}\text { Generate surface runoff higher than soils from Group B, with BIV between } \\
1.27 \text { e } 3.81 \mathrm{~mm} \mathrm{~h}^{-1} \text {. Deep to moderately deep soils }(0.5 \text { a } 2.0 \mathrm{~m}) \text {, with high } \\
\text { surface permeability and high horizon A/horizon B texture transition ratio } \\
\text { lower than } 1.2 \text {. Low surface permeability and strong textural transition from } \\
\text { A to B horizon }(>1.5) \text {. Low resistance to erosion. }\end{array}$ \\
\hline $\mathrm{D}$ & $\begin{array}{l}\text { Shallow soils with low infiltration capacity and greater capacity to generate } \\
\text { surface runoff }\left(\mathrm{BIV}<1.27 \mathrm{~mm} \mathrm{~h}^{-1}\right) \text {. Moderately deep to shallow soils }(0.25 \\
\text { a } 1.0 \mathrm{~m} \text { ) with impediment layer near horizon A and without defined B } \\
\text { horizon. High vulnerability to erosion. }\end{array}$ \\
\hline
\end{tabular}

After this procedure, each HG was represented by the mean value of the corresponding infiltration capacity interval, which came to represent the soil class, weighted by their relative participation in the soil mapping unit, in order to obtain a weighted final value, which was reinterpreted as the framework of the mapping unit in the HG's.

The precipitation, relief and soil characteristics of three different hydrographic regions of Minas Gerais State were used to evaluate the consistency of the procedure, represented by the water resources planning and management units (WRPMU) identified below: GD1 is part of the Grande River Basin and covers the Upper Grande River Region in the south of Minas Gerais State; SF5 includes the Velhas River Basin and SF10 includes the Verde Grande River Basin, both are parts of the São Francisco River Basin, whose drainage areas are respectively: 8,781.6; $28,005.5$ and $26,949.1 \mathrm{~km}^{2}$. 


\section{RESULTS AND DISCUSSION}

Figure 2 presents the proposed classification of the pedological units mapped in the Minas Gerais State in hydrologic groups by the SCS-CN method.

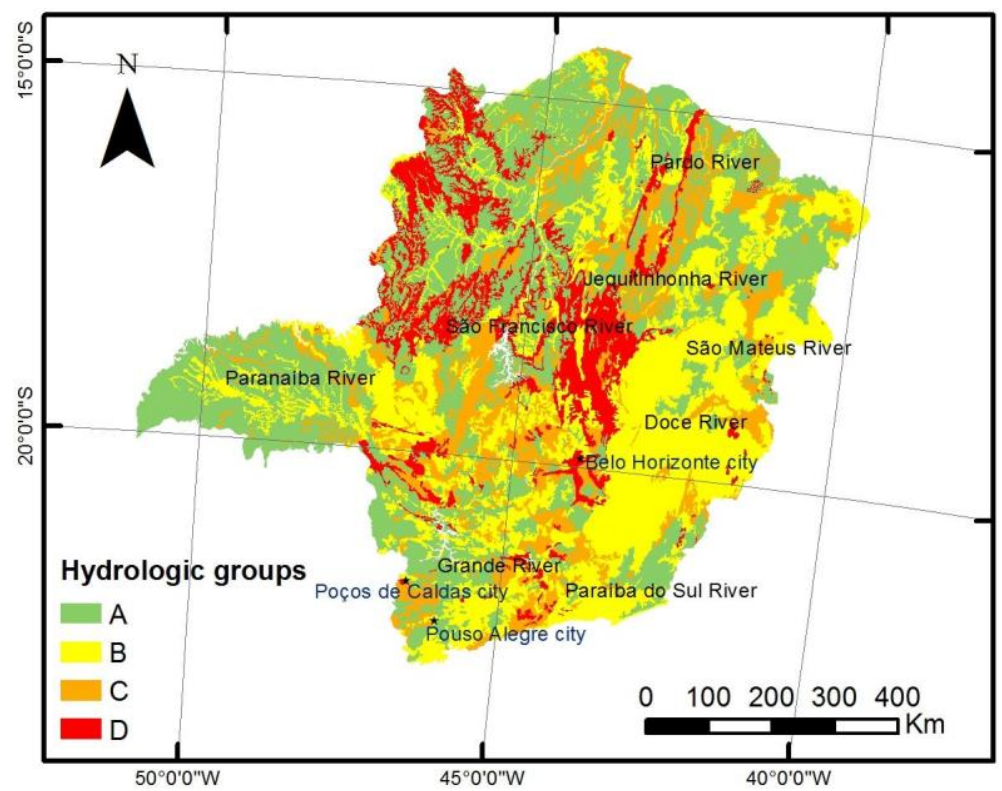

Figure 2. Classification of the pedological units mapped in the Minas Gerais State in hydrologic groups by the Curve Number method.

Group A can be represented by the class of Latosols and the Group B by the Acrisols. Group C is represented mainly by the Cambisols and the Group D by the Leptosols, Arenosols, Fluvisols and rock outcrops. In general, there is a predominance of hydrologic Groups A and B, which together occupy about $71 \%$ of the area of the state (Figure 2 and Table 3).

$\begin{aligned} & \text { Table 3. Percentage of each } \\
& \text { Hydrological Group in the Minas Gerais } \\
& \text { State }\end{aligned}$
\begin{tabular}{cc} 
Hydrological Group & Area $(\%)$ \\
\hline A & 38.48 \\
B & 32.64 \\
C & 17.32 \\
D & 11.56 \\
\hline
\end{tabular}

The HG's map for Minas Gerais State (Figure 2) shows that most of the state belongs to Group A (38.48\%), followed by Group B (32.64\%) (Table 3). These two groups are characterized by low surface runoff and high water infiltration rates in the soil profile. Groups $\mathrm{C}$ and D occupy 17.32 and $11.55 \%$ of the area of the State, respectively, and are associated with regions with the potential to generate higher surface runoff rates, due to the lower water infiltration rates in the soil profile.

The HG A areas are mainly concentrated in the Triângulo Mineiro region (watersheds of the lower Grande and Paranaíba Rivers), a large part of the north and northeast of the State, covering the basins of the São Francisco, Pardo, Jequitinhonha, Mucuri and São Mateus Rivers (Figure 2).

\section{IPABH}


The Grande River Basin presents a mosaic, with hydrologic Groups A, B and C. The HG $\mathrm{C}$ is associated mainly with the Mantiqueira Range formations and the Cambisols existing between Poços de Caldas and Pouso Alegre cities. The hydrologic Group B appears concentrated in the southern portion of this basin, where Acrisols dominate, under undulated to strongly undulated relief. Thus, in the Upper Grande River region, there is predominance of HG's B and C, due to the presence of Red-Yellow Latosols, with blocky structure, and Cambisols, which are less developed soils, presenting characteristics that restrict the water infiltration in the soil profile (Brandão et al., 2007; Resende et al., 2014).

In the lower region of the Grande River, HG A soils predominate, which presents occurrence of Red Latosols, which are well-developed soils with granular structure (Resende et al., 2014), presenting a high rate of natural infiltration of water in the soil profile.

In the western part of the Paranaíba River Basin (Triângulo Mineiro region), the HG A predominates, due to the Red Latosols arising from the weathering of the sedimentarymagmatic rocks of the geological unit of the Paraná Basin (Machado and Silva, 2010), with occurrence of areas inserted in $\mathrm{HG} \mathrm{C}$, following the main water courses, restricting the water infiltration into the soil by the occurrence of floodplain soils (Resende et al., 2014). On the other hand, in the eastern portion, near the municipality of Araxá, there is a concentration of soils of HG B related to the presence of Cambisols under gently undulated to undulated relief.

Slope is a topographic attribute widely used in environmental studies because it exerts a great influence on the water flow, and therefore on the speed with which superficial and subsuperficial runoff occurs. Flauzino et al. (2010), in a characterization of the Paranaíba River Basin, mention that the areas within this basin have less than $8 \%$ slope, and $66.63 \%$ of the study area is located in areas with Latosols, which promote a higher permeability of water in the soil profile and, consequently, a decrease in the rate of direct surface runoff.. In the northern portion of the Paranaíba River Basin, there is a narrow strip with a predominance of soils of the HG D, associated to the Leptosols under strongly undulated to mountainous relief.

In the São Francisco River Basin, most of the soils classified as HG D in Minas Gerais State are concentrated, which is related to the lithological diversity found in the São Francisco Craton. In the south of the basin is the Quadrilátero Ferrífero region, formed by diverse metamorphic rocks and undulated to mountainous relief from which the Leptosols and rock outcrops. These areas are associated with gentle reliefs and poorly developed soils which restrict water infiltration into the soil.

To the north of the São Francisco River Basin, there is the occurrence of HG A, due to the presence of Latosols and Arenosols in this region, facilitating the percolation of water in the soil profile. Fernandes et al. (2013) cite the predominance of large areas of Fluvisols in the river plains (or lower alluvial terraces) in this part of the Minas Gerais State and which are inserted in HG's B and C (Figure 2).

In the Northeast Rivers' basins (Pardo River, Jequitinhonha River, Mucuri River and São Mateus River), there is a great heterogeneity of HG's. HG B appears concentrated in the São Mateus River Basin, and along the Jequitinhonha River. At the headwater of the São Mateus River Basin, soils of the HG D also occur, because of the Espinhaço Range, with shallow soils and high slope. According to Fernandes et al. (2013), the Alto Jequitinhonha region presents rocky outcrops with sandy ramps associated with organic soils, rupestrian field, and fieldsavannah. There is a predominance of Arenosols, which are poorly developed soils, with a serious limitations in relation to water storage capacity, and therefore prone to the generation of surface runoff.

The Doce and Paraíba do Sul Rivers have a high concentration of HG B soils associated with the expression of Acrisols in undulated and strongly undulated relief, typical of the eastern part of these basins in combination with Red-Yellow Latosols in mountainous relief. An 
important feature of these two river basins is the occurrence of floods in several municipalities, especially those where HG B soils predominate. One of the explanations for the occurrence of these types of phenomena is linked to the influence of the forest in the soil hydrology, highlighting the interaction between interception and the direct impact of very intense rainfall at the surface (Pinto et al., 2017). The Atlantic Forest, which was replaced mainly by pastures and later by eucalyptus plantations, was the original ecosystem in the Rio Doce Basin; however, today it covers mostly fragmented remnants.

\subsection{Background from three water resources planning and management units (WRPMU)}

In order to validate and better understand the interpretation of soil mapping units of the Minas Gerais State from the perspective of the Hydrologic Groups, three WRPMU were analyzed taking as a basis the characteristics of precipitation, relief, and soil.

The hydrographic regions used were WRPMU GD1 (Upper Grande River Basin), WRPMU SF5 (Velhas River Basin) and WRPMU SF10 (Verde Grande River Basin).

It should be emphasized that the presented results follow the same referential as the soil class intervals adopted for the Minas Gerais State as a whole, resulting in a more general approach. This is necessary, however, so as not to change the reference that will allow a comparison between the hydrographic regions analyzed. In the case of a specific analysis for a certain hydrographic region, we can opt for the greater detailing of the spatial distribution of its attributes.

The rainfall regime of the three hydrologic regions, represented by the average annual precipitation, can be analyzed based on the information contained in Figure 3, which allow visualizing the spatial distribution and the frequency of the precipitation classes.

The class intervals did not allow greater differentiation of the pluvial regime within a same hydrographic region, with each WRPMU having its area characterized by only two classes of annual precipitation; however, the comparative analysis allows to distinguish them.

WRPMU GD1 is characterized by a high pluvial regime with a predominance of the class between 1200 and $1500 \mathrm{~mm}$, having a significant presence of the class $>1500 \mathrm{~mm}$ which, on average, raises its rainfall index (Figure $3 \mathrm{~A}$ ).

According to Figure 3B, WRPMU SF5 shows a predominance of the precipitation class between 1200-1500 $\mathrm{mm}$.

The WRPMU SF10 rainfall regime is characterized in Figure 3C, where there is a high frequency in the precipitation class $<900 \mathrm{~mm}$, which makes it the lowest total annuals.

This characterization also allowed us to verify that the regions present clearly within their territorial space decreasing gradients in their rainfall indexes where the highest values occur at their headwaters and between regions, which indicates the potentiality of differentiation in the capacity to generate direct surface runoff.

The relief of WRPMU's represented by slope classes is shown in Figure 4. 

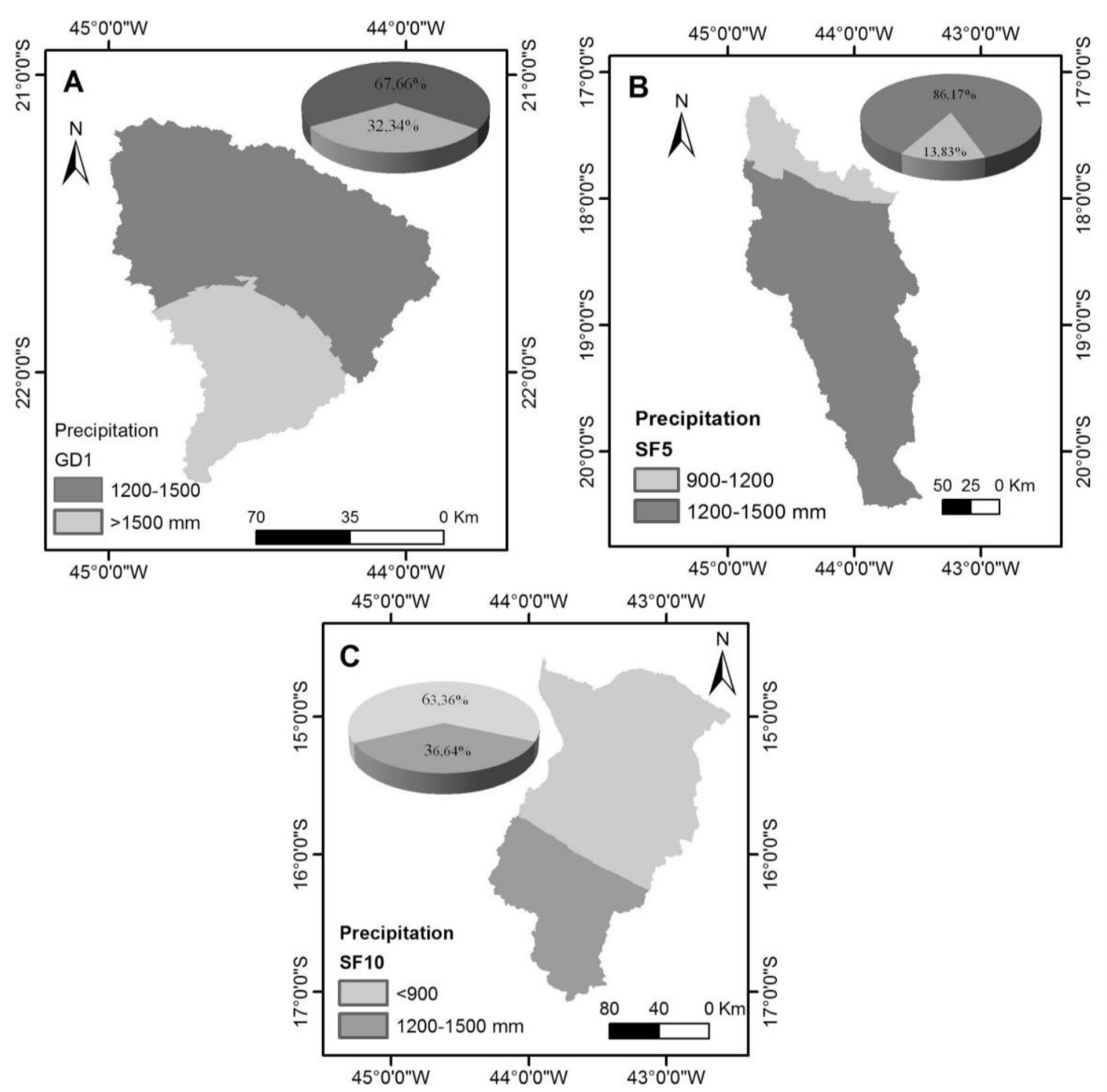

Figure 3. Spatial distribution and the frequency of the precipitation classes to the WRPMU's GD1 (A), SF5 (B) e SF10 (C). 


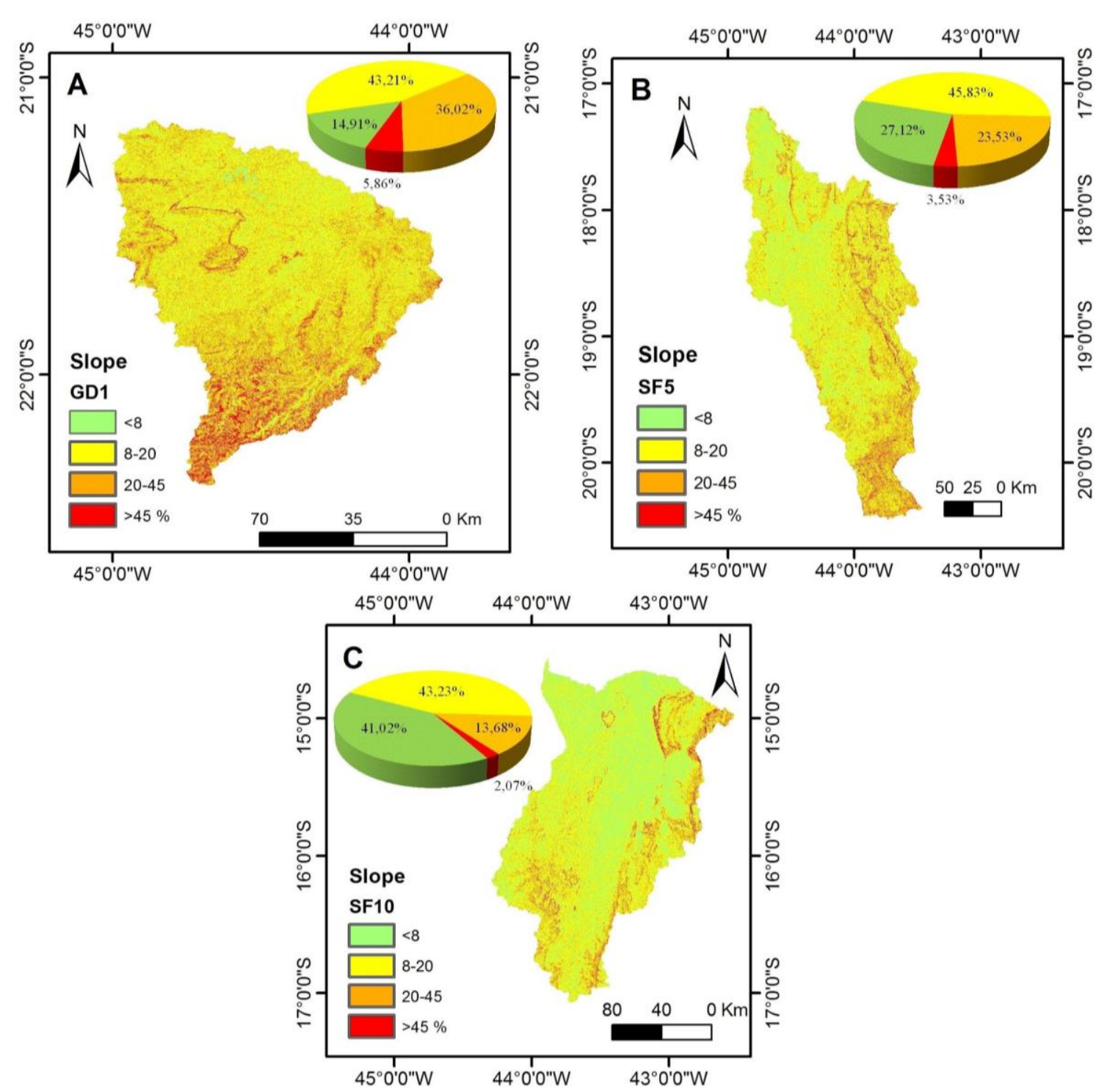

Figure 4. Spatial distribution and the frequency of the slope classes to the WRPMU's GD1 (A), SF5 (B) e SF10 (C).

WRPMU GD1 (Figure 4A) presents an expressive occurrence of two slopes classes, $8-20 \%$ and $20-45 \%$, which results in a high average slope. Furthermore, the highest percentages of the slope are in the 8-20\% class (Figure 4A); however, there is a high frequency of areas near two other slope classes, which indicates an average value within the highest frequency class.

WRPMU SF10 presents predominance of two classes of slopes $8-20 \%$ and $<8 \%$ (Figure 4C), which leads to an average slope below the other WRPMU's, favoring a higher water infiltration rate in the soil and lower surface runoff rate.

The set of information regarding the relief showed that the WRPMU's have different slopes between them, and also have slope gradients within the units, from the headwater to the mouth.

WRPMU GD1 presents the highest percentages of slope in the class $>45 \%$ in relation to the other WRPMU's (Figure 4A). The highest percentages of slope in this region are in the southern part where the source of Grande River is located. This verifies that the greater slope percentages in the WRPMU GD1 potentiate the generation of direct surface runoff.

Figure 5 presents the map of the spatial distribution of HG's and the frequency (\%) of their classes for the WRPMU's GD1, SF5, and SF10. 


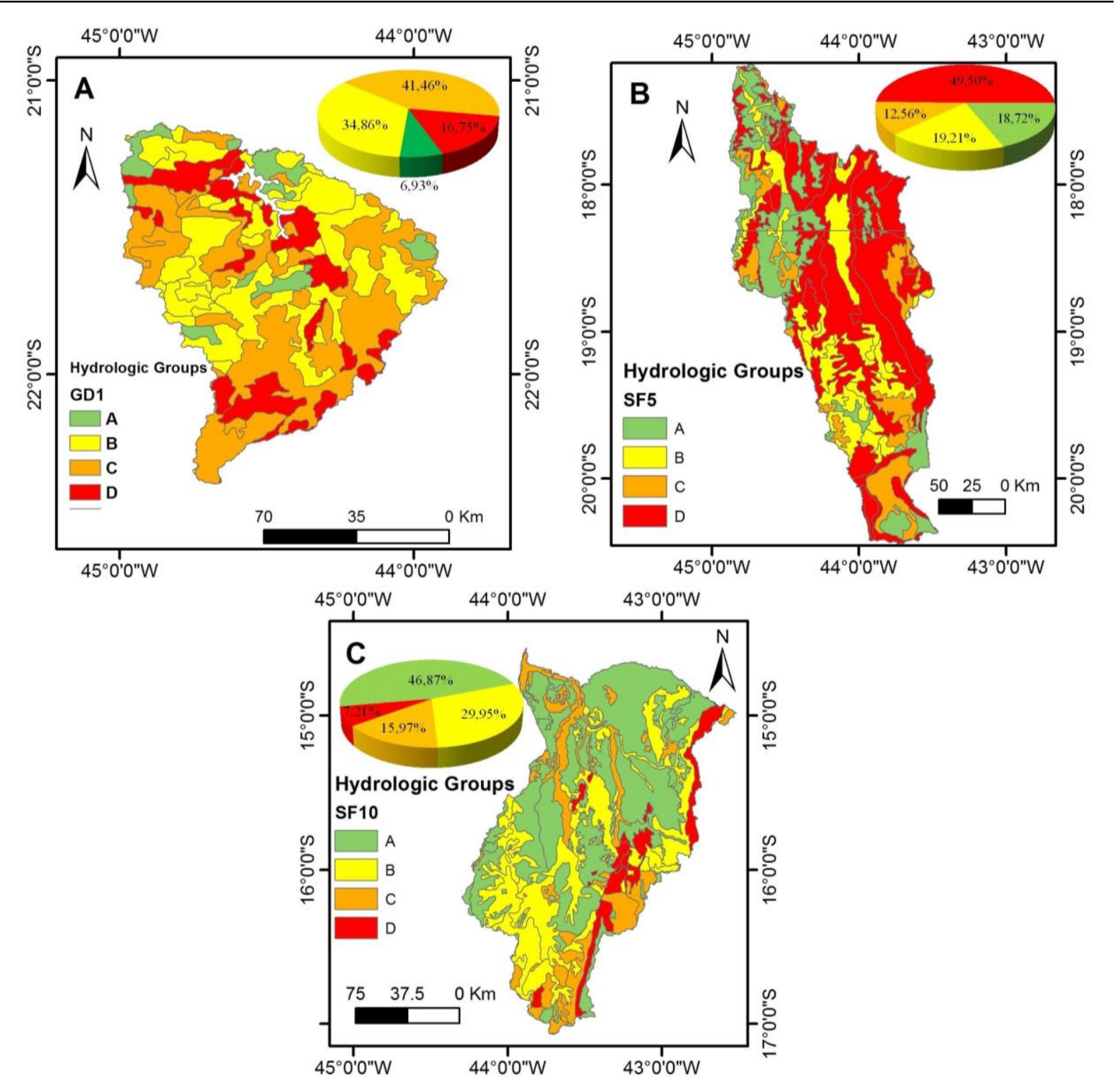

Figure 5. Spatial distribution and the frequency of the Hydrologic Groups to the WRPMU's GD1 (A), SF5 (B) e SF10 (C).

According to Figure 5A, in WRPMU GD1 the highest percentage of HG C is associated with the highest occurrence of Cambisols (Menezes et al., 2009).

In a hydraulic conductivity analysis of this region, Alvarenga et al. (2011) verified high values of two distinct regions, the Upper Grande River Basin, within GD1 in the Mantiqueira Range region, and in the Latosol sites in the northern part of the WRPMU GD1. The authors pointed out for this behavior the hypothesis raised by Menezes et al. (2009), wherein the most prominent relief region within WRPMU GD1 the soils are basically Cambisols, but they present predominant land-use like Atlantic Forest, which provides greater organic matter content on the soil surface, favoring the water infiltration process (Pinto et al., 2017; 2018). Another hypothesis was raised by Gomes et al. (2007), that in the region with soft relief and predominance of Latosols, soils which present important pedological characteristics in the context of water infiltration, especially because of the granular structure, constitute expressive areas for groundwater recharge. However, they are very susceptible to degradation due to inappropriate soil management. 
The presence of fluvial plains in the region of WRPMU GD1 is characterized by inexpressive infiltration capacity, due to the presence of Fluvisols with the proximity of the soil layers to the water table, and the presence of floods in this soil class (Fernandes et al., 2013).

There is also the presence of fluvial terraces in flat relief within the WRPMU GD1, with a predominance of Cambisols. According to Brandão et al. (2007), the vegetation suppression in this type of soil leads to the occurrence of crusting and erosion in gullies, which limits the infiltration of water in the soil profile.

The highest percentage of HG D in WRPMU SF5 is associated with Cambisols, which are the highest-occurring soils in this WRPMU (Figure 5B). Silva et al. (2012), in an analysis of the landscape in this region, cite the occurrence of Cambisols, Leptosols and rock outcrops, associated with rupestrian fields.

According to Figure 5C, the highest percentage of Hydrologic Group A in WRPMU SF10 is associated with soils with characteristics of greater permeability such as Latosols and Arenosols, therefore characterizing regions with lower surface runoff rate.

Ogden et al. (2017) demonstrated the need to advance in the use of other methodologies, going beyond the SCS-CN method, e.g., using data collection to obtain significant parameters from a wide variety of hydro-geographic configurations. We emphasize that our results are important because the proposed analysis is particularly useful, since in the SCS-CN method the characterization of soil type under the $\mathrm{CN}$ perspective is not available and since this empirical and simple method is still widely applied.

Therefore, the interpretation of soil mapping units from the perspective of the Hydrological Groups has shown to be a promising tool to assist in understanding the flow regime of the analyzed hydrological regions.

\section{CONCLUSIONS}

Most of the Minas Gerais State fits in Hydrologic Groups A and B, indicating that the soils in these areas present low surface runoff and high water infiltration rates.

The characterization and spatialization of the hydrological regime applied in this study, with emphasis on information regarding the soils of Minas Gerais State, has a level of detail not yet employed in studies of this scope, including the initiative to interpret them from the perspective of soil hydrological groups.

The mapping of the three water resources planning and management units, composed of distinct environments, and from the perspective of hydrological groups, allowed us to verify the potentiality of the proposed methodology, which can be used to support the management and planning of the water resources of Minas Gerais State.

Studies on interpretations of soil maps from the point of view of hydrological studies are essential to improve studies of water surpluses.

\section{ACKNOWLEDGMENTS}

The authors would like to thank CNPq, FAPEMIG, and CAPES funding agencies, which provided the financial support for the development of this work. We extend our thanks to Dr. Carlos Rogério de Mello and Dr. Nilton Curi of the Federal University of Lavras for collaboration on the soil hydrology investigations. Additionally, we would like to thank the editor and anonymous reviewers for their extensive comments and suggestions, which have made this a significantly stronger contribution. 


\section{REFERENCES}

ALVARENGA, C. C.; MELlO, C. R.; MELlO, J. M.; VIOLA, M. R. Continuidade espacial da condutividade hidráulica saturada do solo na bacia hidrográfica do Alto Rio Grande, MG. Revista Brasileira de Ciência do Solo, v. 35, n. 5, p. 1745-57, 2011. https://doi.org/10.1061/(ASCE)0733-9429(1995)121:2(171)

ARNOLD, J. G.; WILLIAMS, J. R.; MAIDMENT, D. R. Continuous-time water and sediment routing model for large basins. Journal of Hydraulic Engineering, v. 121, n. 2, p. 17183, 1995.

BRANDÃO, V. S.; SILVA, D. D.; RUIZ, H. A.; PRUSKI, F. F.; SCHAEFER, C. E. G. R.; MARTINEZ, M. A. et al. Perdas de solo e caracterização física e micromorfológica de crostas formadas em solos sob chuva simulada. Engenharia Agrícola, v. 27, n. 1, p. 12938, 2007. http://dx.doi.org/10.1590/S0100-69162007000100006

FERNANDES, M. R.; LEAL, J. T. C. P.; MELLO, M. S.; MOREIRA, M. A. B. ALBANEZ, A. P. Minas Gerais: caracterização de unidades de paisagem. Belo Horizonte: EMATER, 2013. $92 \mathrm{p}$.

FIORI, J. P. O.; CAMPOS, J. E. G.; ALMEIDA, L. Variabilidade da condutividade hidráulica das principais classes de solos do Estado de Goiás. Geociências, v. 29, n. 2, p. 229-235, 2010 .

FLAUZINO, F. S.; SILVA, M. K. A.; NISHIYAMA, L.; ROSA, R. Geotecnologias aplicadas à gestão dos recursos naturais da bacia hidrográfica do Rio Paranaíba no cerrado mineiro. Sociedade \& Natureza, v. 22, n. 1, p. 75-91, 2010.

FUNDAÇÃO ESTADUAL DO MEIO AMBIENTE (FEAM). Mapa de solos do estado de Minas Gerais. Belo Horizonte, 2010.

GOMES, N. M.; FARIA, M. A.; SILVA, A. M.; MELLO, C. R.; VIOLA, M. R. Variabilidade espacial de atributos físicos do solo associados ao uso e ocupação da paisagem. Revista Brasileira de Engenharia Agrícola e Ambiental, v. 11, n. 4, p. 427-435, 2007.

GRIMALDI, S.; PETROSELLI, A.; ROMANO, N. Curve-Number/Green-Ampt mixed Procedure for Streamflow Predictions in Ungauged basins: Parameter Sensitivity Analysis. Hydrological Processes, v. 27, n. 8, p. 1265-1275, 2013. http://dx.doi.org/10.1002/hyp.9749

MACHADO, M. F.; SILVA, S. F. Geodiversidade do Estado de Minas Gerais. Belo Horizonte: CPRM, 2010. $131 \mathrm{p}$.

MCCUEN, R. H. Hydrologic Analysis and Design. Englewood Cliffs: Prentice Hall, 1998. $814 \mathrm{p}$.

MELLO, C. R.; SILVA, A. M. Hidrologia: princípios e aplicações em sistemas agrícolas. Lavras: UFLA, 2013. 455 p.

MELLO, C. R.; NORTON, L. D.; PINTO, L. C.; BESKOW, S.; CURI, N. Agricultural watershed modeling: a review for hydrology and soil erosion processes. Ciência e Agrotecnologia, v. 40, n. 1, p. 7-25, 2016. http://dx.doi.org/10.1590/S141370542016000100001 
MENEZES, M. D.; JUNQUEIRA JÚNIOR, J. A.; MELLO, C. R.; SILVA, A. M.; CURI, N.; MARQUES, J. J. Dinâmica hidrológica de duas nascentes, associada ao uso do solo, características pedológicas e atributos físico-hídricos na sub-bacia hidrográfica do Ribeirão Lavrinha-Serra da Mantiqueira (MG). Scientia Forestalis, v. 37, n. 82, p. 17584, 2009.

OGDEN, F. L.; HAWKINS, R.; WALTER, M. T.; GOODRICH, D. C. Comment on “'Beyond the SCS-CN method: A theoretical framework for spatially lumped rainfall-runoff response' by M. S. Bartlett et al. Water Resources Research, v. 53, p. 6345-6350, 2017. http://dx.doi.org/10.1002/2016WR020176

PINTO. L. C.; MELLO, C. R.; NORTON, L. D.; SILVA, S. H. G.; TAVEIRA, L. R.; CURI, N. Land-use effect on hydropedology in a mountainous region of Southeastern Brazil. Ciência e Agroctecnologia, v. 41, n. 4, p. 413-427, 2017. http://dx.doi.org/10.1590/1413-70542017414002017

PINTO. L. C.; MELLO, C. R.; NORTON, L. D.; POGGERE, G. C.; OWENS, P. R.; CURI. A hydropedological approach to a mountainous Clayey Humic Dystrudept. Scientia Agricola, v. 75, n. 1, p. 60-69, 2018. http://dx.doi.org/10.1590/1678-992x-2016-0144

RESENDE, M.; CURI, N.; REZENDE, S. B.; CORREAA, G. F.; KER, J. C. Pedologia: base para distinção de ambientes. 6. ed. Lavras: UFLA, 2014. 378 p.

SARTORI, A.; LOMBARDI NETO, F.; GENOVEZ, A. Classificação hidrológica de solos brasileiros para estimativa da chuva excedente com o método do serviço de conservação do solo dos Estados Unidos. Parte 2: Aplicação. Revista Brasileira de Recursos Hídricos, v. 10, n. 4, p. 5-18, 2005.

SILVA, L. C. L.; AGUILAR, B. F.; DIAS, J. B.; CARMO, V. A.; COSTA, A. M.; JARDIM, C. H. Análise da paisagem a partir da estratificação ambiental: Estudo da bacia do córrego Maria Casimira - André do Mata Dentro/MG. Revista Geonorte, v. 3, n. 4, p. 518-29, 2012. 